\title{
An Orthodox and Byzantine Reception of the Elements of Theology
}

\author{
Frederick Lauritzen \\ Scuola Grande di San Marco, Venezia
}

The question of the existence of Byzantine philosophy may be intellectually interesting but remains fundamentally surreal. ${ }^{1}$ Regardless of whether one defines the Byzantine Empire as beginning with Diocletian (284-305), Constantine (306-337) or Theodosius (379-395), it is clear that Proclus (8th February 412-17th April 485) composed his text within an Empire whose capital was Constantinople, and whose official religion was Christianity since 27th February $380 .{ }^{2}$ While this may be obvious, it is interesting for the reception of Proclus' Elements of Theology, a text that was composed within a Byzantine background and whose subsequent translations where done from originals copied within the Byzantine Empire.

It is such an environment which gave rise to the anecdote that Proclus advised the emperor Anastasius (491-518) on how to defeat an invading enemy army with Greek fire. ${ }^{3}$ The story gives us a non-philosophical explanation to the

1 An overview of intellectual history is Kaldellis and Sinissioglou (2017).

2 Codex Theodosianus, xvi.1.2 = Codex Iustiniani 1.1.1. Cfr. Basilicorum libri LX, 1.1.1: Imppp. gratianus, Valentinianus et Theodosius aaa. edictum ad populum urbis Constantinopolitanae. cunctos populos, quos clementiae nostrae regit temperamentum, in tali volumus religione versari, quam divinum Petrum apostolum tradidisse romanis religio usque ad nunc ab ipso insinuata declarat quamque pontificem Damasum sequi claret et Petrum Alexandriae episcopum virum apostolicae sanctitatis, hoc est, ut secundum apostolicam disciplinam evangelicamque doctrinam Patris et Filii et Spiritus Sancti unam deitatem sub parili maiestate et sub pia Trinitate credamus. ( 380 febr. 27$)$.

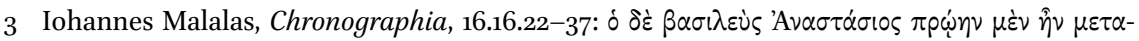

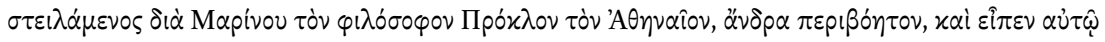

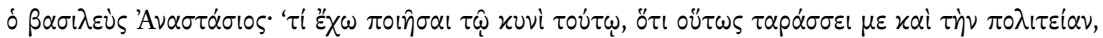

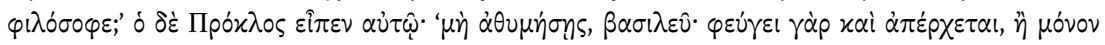

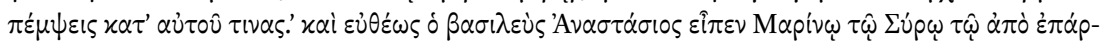

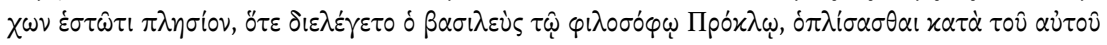

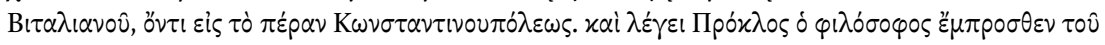

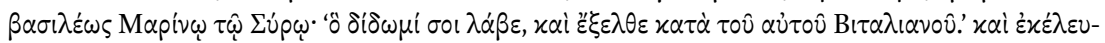

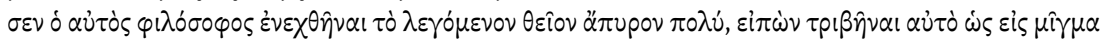


importance of Proclus and his philosophical research. The Elements of Theology employed a sort of scientific method, familiar from Euclid, which was part of child's education, and explained terms which were mysteriously present in such concise authors as Dionysius the Areopagite. The tenth-century Suda refers to Proclus as a plagiarist of Dionysius:

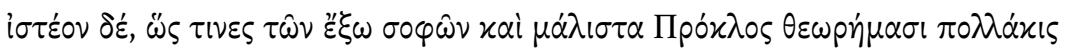

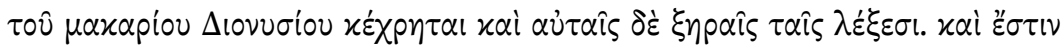

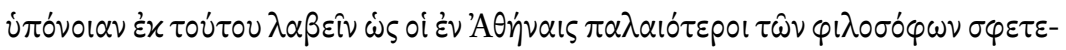

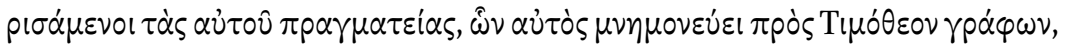

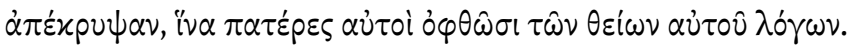

Suda $\Delta .1170 .80-86$

One should know that some pagan thinkers and especially Proclus often employ ideas and even entire expressions [taken from] the blessed Dionysius. One may suspect that they took them from him, since the more ancient philosophers in Athens appropriated and hid his material, as he himself reminds us when he writes to Timotheos, so that they would appear as the authors of his divine words.

That a sixth century historian from Antioch or a tenth century encyclopaedia could refer so easily to Proclus is simply because his philosophy was known even to non-specialists. Indeed, Proclus permeates Byzantine thought everywhere. The result of this was that those western scholars who could read Greek found Proclean ideas present in all forms of Byzantine manuscripts both within the texts and the margins, and it was only recently that ancient philosophers have been separated from such Proclean influence. ${ }^{4}$ The step away from such a peculiar and Byzantine choice of philosophy to saying that there is no such thing as Byzantine philosophy is as if an analytical thinker said that Hegel (1770-1831) was not a philosopher since he did not share their

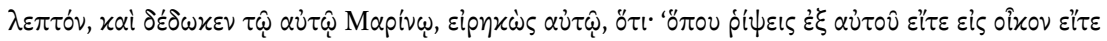

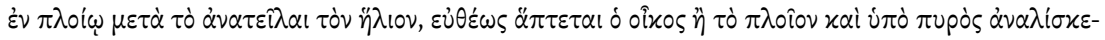
$\tau \alpha l^{\prime}$

4 Hegel himself claims that in the Phenomenology of Spirit that the best reading of Plato's Parmenides was that of Proclus: "der Parmenides des Plato, wohl das größte Kunstwerk der alten Dialektik, für die wahre Enthüllung und den positiven Ausdruck des göttlichen Lebens gehalten wurde" (Hegel 1807, p. 48) ["when the Parmenides of Plato-perhaps the greatest literary product of ancient dialectic - has been taken to be the positive expression of the divine life, the unveiling and disclosing of its inmost truth."] 
methods and conclusions. One should remember that Hegel in his time had been defined as the 'German Proclus.' ${ }^{5}$

The history of philosophy is full of enlightened individuals who were not understood in their time or their country and often made a career of such complaints. It is for this reason this paper focuses on the reception of the Elements of Theology in three major Byzantine authors: Maximus the Confessor (579-662), Michael Psellos (1018-1081), Gregory Palamas (1296-1359). A brief word about them will show that, with the eye of hindsight, they are not exceptional but representative of Byzantine culture. Maximus the Confessor was regarded as a Saint in the Byzantine church and the sixth ecumenical council of 68o-681 was convened explicitly to confirm and support his ideas. ${ }^{6}$ Michael Psellos could be considered an eccentric thinker, except he was appointed consul of the philosophers in 1047 by the emperor and his over 1000 works survive in ca 1700 manuscripts, ${ }^{7}$ which defines his success and clear reception, but almost exclusively among Byzantines. ${ }^{8}$ Gregory Palamas in the fourteenth century defined Byzantine mysticism, known as hesychasm, and his ideas were endorsed officially in 1341,1347 and $1351 .{ }^{9}$ Moreover his ideas were once more defended in 1368, the synod which condemned Thomas Aquinas (1224-1274) and in which Palamas was declared a Saint of the Orthodox Church.

The reception of the Elements of Theology in these authors is representative. If one may start with the eleventh century the easiest case is that of Michael Psellos who was directly interested in the Elements of Theology. Indeed, he quotes the following propositions directly:

- in Philosophica Minora I, he cites the Elements of Theology 102, 110, 116, 140

- in Philosophica Minora II, he cites the Elements of Theology 20, 35, 39, 64, 81, 9o, 103, 109, 110, 129, 166-168, 170-196, 198-202, 204-206, 208-211

Psellos openly refers to Proclus and uses his ideas to explain obscure points of ancient philosophy, or as instruments to solve dilemmas of contemporary theology. Psellos also explains a point of orthodox mysticism employing directly proposition 71 of the Elements of Theology in Theologica I essay 11 (uncreated light of Mt Tabor). ${ }^{10}$ Psellos did not think it was problem to study a pagan thinker like Proclus and it even made him popular at the imperial court where

\footnotetext{
5 L. Feuerbach, Grundsätze einer Philosophie der Zukunft, p. 87-171 paragraph 29.

6 COGD 1. 195-202.

7 Moore (2005).

8 One exception was Marsilio Ficino who translated some of his works into Latin especially on demonology.

9 COGD 4.133-152. COGD 4.155-170. COGD 4.171-218.

10 Lauritzen (2012a).
} 
he obtained the title of consul of philosophers ( The peculiar status of Psellos, whatever one may think of him, is that he was popular among contemporaries and was a well-read author for the next four hundred years. He provided an acceptable method of reading Proclus which reveals the Byzantine fascination with later Neoplatonism. Scholars tend to emphasize his role as a teacher, often reflecting their own interests. More than half of Psellos' letters are written to members of the imperial bureaucracy and

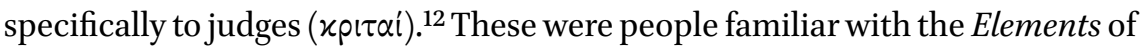
Euclid but interested in philosophy. There is even evidence of study of Proclus' commentary on the Elements of Euclid in the eleventh century. ${ }^{13}$ Their duty consisted of applying their notions of geometry to land measurement for tax assessment. ${ }^{14}$ Thus the Elements of Theology may have appealed to the educated Byzantine bureaucrat specifically for this reason: the form was familiar and useful, but the content was philosophical. If Psellos was not an original thinker, ${ }^{15}$ which is possible but needs to be investigated, then he was able to express correctly what intelligent readers wanted to hear. This is where Maximus the Confessor becomes important. In his letter to Patriarch Xiphilinos, Psellos argues that he reads Plato correctly and especially since his reading corresponds to that given by Maximus the Confessor:

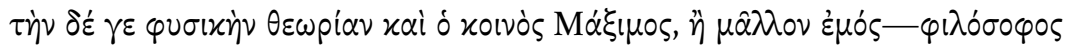

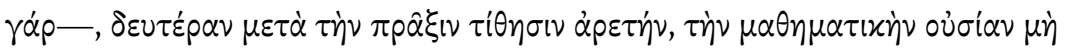
$\pi \rho \circ \pi 010$ ú $\varepsilon v 0 \varsigma$.

michael PSELlos, Ep. Xiphil. 72-75

Our, or rather, my Maximus, for he is a philosopher, considers natural contemplation as the second virtue after praxis, without considering mathematical substance.

Psellos here argues succinctly that above the visible world, there is an incorporeal world which also exists. Indeed, the principles which define the visible world also have a form of existence. These are the principles, or what Maximus calls the $\Lambda$ 'rol, which may be contemplated and maybe even studied. This

\footnotetext{
11 Lefort (1976).

12 Jeffreys Lauxtermann (2017).

13 Heiberg (1929) p. 72-75. See Lauritzen (2016).

14 Dölger (1927).

15 Ioannou defined him as Weiblich in contrast with Italos (?) in Ioannou (1956) p. 16.
} 
becomes an important doctrine especially later on in such thinkers as Gregory Sinaites and Gregory Palamas. We will return later to this question. One may develop an aspect which is the notion of what is incorporeal. This had been a problem specifically for Porphyry $(234-305)$ as one may see from Sententia 1 and Sententia 2 which claimed that the incorporeal could be in no place. This meant that demons could not exist since they are incorporeal but have a specific place:

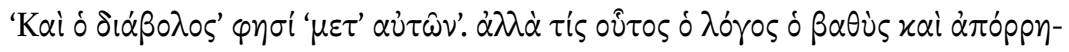

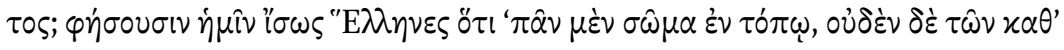

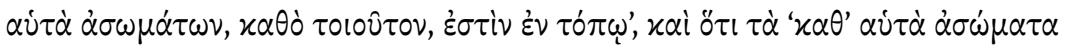

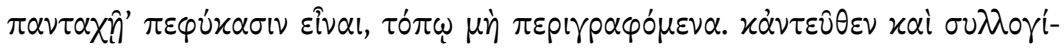

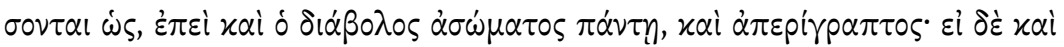

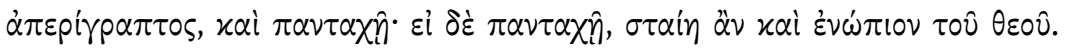

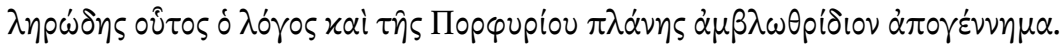

MICHAEL PSELLOS, Theologica I.32.118-125

He says 'And the devil is with them'. But what is this deep and mysterious idea? Maybe the Greeks will tell us that 'each body is in a place, none of the incorporeal beings, as such, are in a place' and that 'the incorporeal beings in themselves are everywhere, not circumscribed in place' and therefore they will also argue that since the devil is incorporeal he is also uncircumscribed. If he is uncircumscribed he is also everywhere. If he is uncircumscribed he would stand also before God. This speech is blasphemous and an aborted offshoot of the madness of Porphyry.

The principle criticized by Psellos is that the incorporeal has a universal existence. Indeed, he indicates that the incorporeal must be understood as separated, as Proclus had done in the Elements of Theology proposition 82. Moreover, the problem with Porphyry is connected with the fact that everything, including the incorporeal, has some form of existence. This is clear from proposition 16 of the Elements of Theology. Proclus defines the incorporeal as something which is capable of reverting to itself (proposition 15) and connects such self-reversion with movement. Since all movement depends on a cause, the incorporeal is part of the level of reality which holds existence. The argument present in Ambigua 7 of Maximus the Confessor is the following:

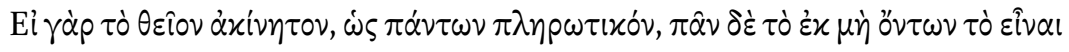

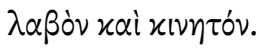

MAXimus The CONFESSOR, Ambigua $7 \cdot 3$ 
If, in the first place, we accept that the divine is immovable (since it fills all things), whereas everything that has received it being ex nihilo is in motion

tr. CONSTAS

Before entering the question of the philosophy behind this passage, the Proclean language is striking. The use of terms such as moving and moved and the idea that existence is secondary and not universal. Moreover, the use of the word 'everything' reminds one of the recurring expressions in the Elements of Theology. To turn to the question of content, if one looks at the expression 'since it fills all things' one may see the echo of the Elements of Theology, proposition 98.29-31:

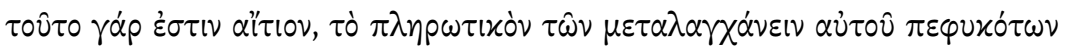

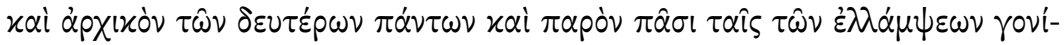

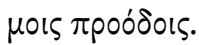

PROCLUS, Elements of Theology, 98.29-31

We mean by cause that which fills all things naturally capable of participating it, which is the source of all secondary existences and by the fecund outpouring of irradiations is present to them all.

tr. DODDS

The second point which echoes Proclus is the idea that being concerns the realm of what is below the divine and that this is defined by movement. This can be seen in the Elements of Theology, proposition 14 where being is defined as moved or unmoved:

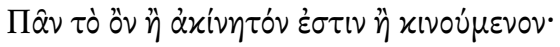

PROCLUS, Elements of theology, 14

All that exists is either moved or unmoved.

tr. DODDS

These two passages from Proclus show how Maximus is employing principles easily found in the Elements of Theology. This occurs rather often. In the passage of Maximus, one should also not neglect that the definition of the divine and the creation ex nihilo are peculiar to a Christian thinker and find echoes of language, but necessarily of content. One may find sources other than Proclus as well, but these are qualified. For example: 


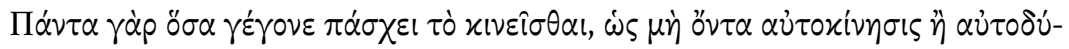

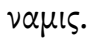

MAXIMUS THE CONFESSOR, Ambigua 7.9

For all things that have come to be passively experience being moved, since they are neither motion itself nor power itself.

tr. CONSTAS

The more usual form is $\alpha \dot{\tau} \tau o x$ เ $\eta \sigma^{\prime} \alpha$, but a peculiar confirmation can be found in John of Damascus who uses Maximus' expression. ${ }^{16}$ The expression avi

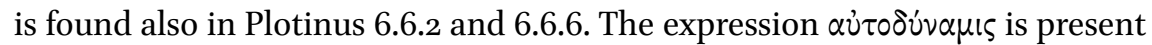
in Dionysius the Areopagite where he indicates clearly that the divine is above self-power. ${ }^{17}$ Thus reflective movements are considered inferior to the Divine itself. Indeed, the passage of Maximus is differentiating between what is and what becomes.

Stepping back briefly one my notice that Maximus is discussing a question

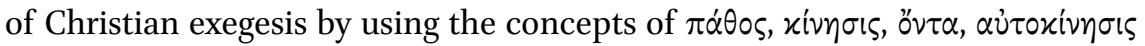

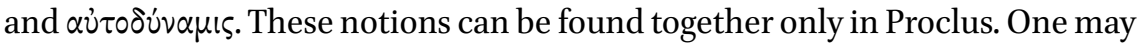
present a passage from the Parmenides commentary where such notions are explained:

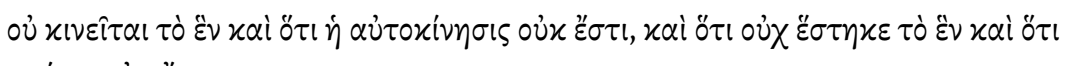

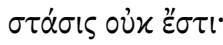

PRoclus, In Parmenidem, 1171.35-37

The One does not move and that selfmovement does not exist and that the One does not rest and that rest does not exist.

The question of rest and motion in relation to the Divine is the aim of the Ambiguum 7 in terms familiar from Proclus. Moreover, Maximus aims to say that the soul is not essentially connected to the divine, since it is logical and always connected to the body. This is the famous doctrine present in Plotinus Enneads 4.8.8 where he says that against platonic doctrine, he believed the upper part of the soul was unified with the one. Proclus thought it was wrong and wrote proposition 211 of the Elements of Theology to prove it:

16 John Damascenus, Epositio fidei, 59.223.

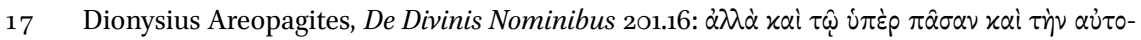

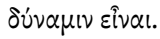




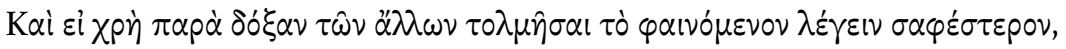

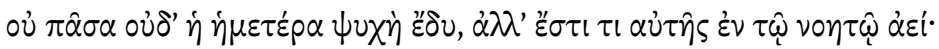

PLotinus, Enneads, 4.8.8.1-3

And if one must dare to speak rather openly against the opinion of others, our soul did not descend entirely, but there is a part of it which is always in the intelligible.

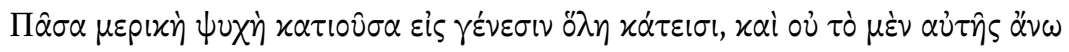

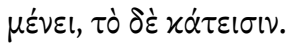

PROCLUS, Elements of Theology, 211

Every particular soul, when it descends into temporal process, descends entire: there is not a part of it which remains above and a part which descends.

Maximus also thinks that it is impossible to separate the body and soul.

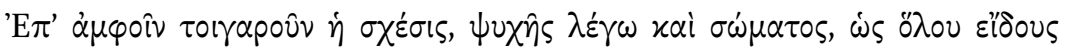

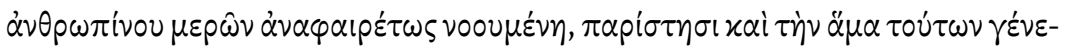
$\sigma i v$.

MAXimus the CONFESSOR, Ambigua $7 \cdot 43 \cdot 1-3$

Thus the relation of the two, by which I mean soul and body, as the whole human form whose parts can be separated only in thought, reveals that both come into being simultaneously.

Thus, one can see that there are linguistic parallels with the Elements of Theology, namely philosophical principles are expressed in a manner similar to Proclus' book of Elements. There are also philosophical principles in common, namely the combination of movement being and the divine. Moreover, the aims are similar. For example, the idea that the soul and body form a unit without there being an intellectual unit with God as Plotinus had proposed.

As Psellos had pointed out in the letter to patriarch Xiphilinos, what Maximus the Confessor did was to study the intermediary realm of reality between God and Man. To provide application to the question of the divine $\lambda$ órol and divine energies as applied to the physical world and therefore to allow their contemplation in his famous $\varphi v \sigma i x \eta \dot{\eta} \theta \varepsilon \omega$ pi $\alpha$. It is for this reason that the council of 68o-681 defined Maximus as correct and a saint. 
If one turns to Gregory Palamas in the fourteenth century, one sees a further development of Proclean influence. The hesychast theologian was accused of being Platonic by one of his adversaries. He acknowledges the attack and gives the following paragraph to describe it:

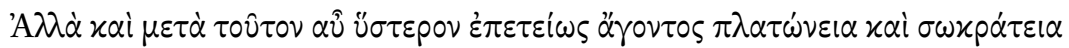

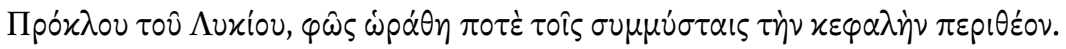

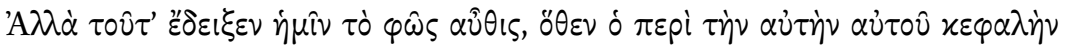

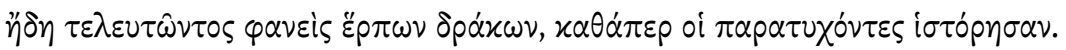

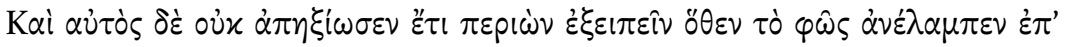

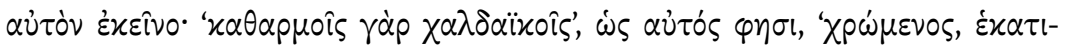

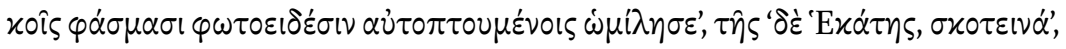
$\varphi \eta \sigma i \nu$ o $\alpha \lambda \eta \theta \dot{\eta} \varsigma \theta \varepsilon o \lambda{ }^{\prime} \gamma \sigma \varsigma$, ' $\tau \dot{\alpha} \varphi \alpha \dot{\sigma} \sigma \alpha \tau \alpha$ '.

gregory Palamas, Contra Acyndinum 7.9.26

Beside Plotinus, Proclus of Lycia was once leading yearly festivals for Plato and Socrates and a light was seen by the initiated surrounding his head. But he showed us the light another time. From it appeared a crawling snake around his head while he was dying. While still alive, he did not refrain from explaining where that light was shining from onto him: as he says 'After completing the Chaldean purifications, he was in touch with enlightened self-revealing apparitions of Hecate' the true theologian says 'the dark apparitions of Hecate'

This explicit reference to Proclus reveals that Palamas was concerned with the contemplation of the divine light within Neoplatonism, such as in proposition 143 of the Elements of Theology

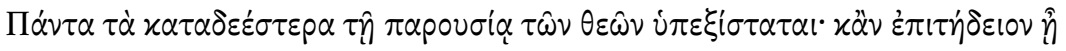

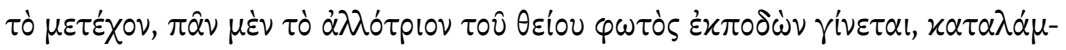
$\pi \varepsilon \tau \alpha l \delta \dot{\varepsilon} \pi \dot{\alpha} \nu \tau \alpha \dot{\alpha} \theta \rho{ }^{\prime} \omega \varsigma$ نं $\pi \dot{o} \tau \hat{\omega} \nu \theta \varepsilon \hat{\omega} \nu$.

PROCLUs, Elements of Theology 143

All inferior principles retreat before the presence of the gods; and provided the participant be fit for it reception, whatever is alien makes way for the divine light and all things are continuously illuminated by the gods.

tr. DODDS 
Interestingly Palamas takes exception not with the theory but with the object of the contemplation. From his point of view, if the content was not true to Christianity it was simply a false contemplation. The nature of such gazing is complicated since the Divine for Palamas is beyond, $\dot{\varepsilon} \pi \varepsilon \dot{\varepsilon} \varepsilon i v \alpha$ as one may see in the following passage:

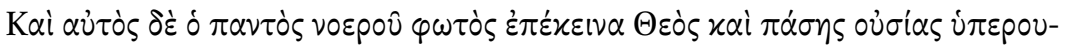

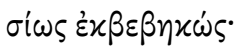

GREOGORY PALAMAS, Triads 1.3.8.10

And God himself who is above all intelligible light and stepping beyond all existence in a supra-essential way.

Such language is again familiar from Proclus, for example proposition 20 defines how the vospós is below the level of the One. ${ }^{18}$ Since the noetic level is connected with being, the divine is also beyond being as said here. Palamas proposes that what is seen is not the divine, but his energies. These had been first proposed by Maximus the Confessor in 634-638 and he had already employed Proclus to develop the theory. ${ }^{19}$ Palamas explicitly quotes Maximus the Confessor as source of such an idea. Because of the details he has to clarify, the theory takes a whole new dimension. One may indicate here that the idea is that the activities may be contemplated but not the Divine itself. Thus, the divine light mentioned above would be considered by Palamas as being the uncreated light seen during the transfiguration of Jesus on Mt. Tabor. Psellos had already associated Proclus' Elements with the study of such perception. ${ }^{20}$ Therefore one may see a direct link between the Proclus' Elements of Theology, Maximus the Confessor's Ambiguum ad Thomam 5 and Palamas.

Psellos makes it easier to understand the link between these three thinkers. Within a Christian environment, one should not forget that when Saint Paul

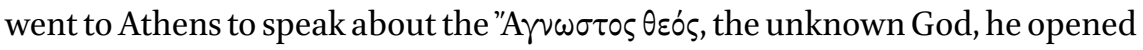
a problem which Psellos solves with the theory of $\lambda$ órol of Maximus and what would become the energies of Palamas:

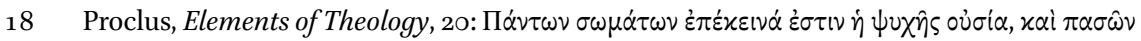

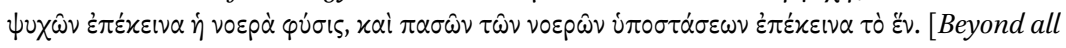
bodies is the soul's essence; beyond all souls, the intellective principle; and beyond all intellective substances, the One.- - tr. Dodds].

19 Lauritzen (2012b).

20 Lauritzen (2012c). 


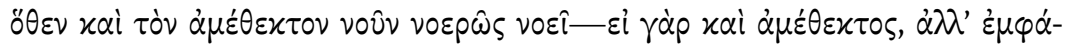

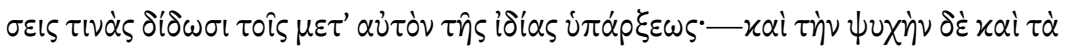

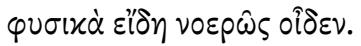

MICHAEL PSELLOS, De omnifaria doctrina $25 \cdot 5^{-8}$

Therefore it perceives the intellect intelligibly, for if it is unparticipated, nevertheless it gives manifestations of its own existence to those after it, and it knows the soul and the physical forms intelligibly.

One should also not forget that for the Byzantines the person who listened to Saint Paul was Dionysius the Areopagite, the first convert of Athens, and alleged writer of the most important philosophical treatises for any orthodox Byzantine of Psellos' era.

Therefore, one may conclude that the $\varphi v \sigma i x \dot{\eta} \theta \varepsilon \omega p i \alpha$ of Maximus and the contemplation of the divine energies described by Palamas have echoes of the Elements of Theology. Both these theories were important for the formation of Byzantine philosophy. The fact that the Byzantines used a pagan Neoplatonic text to explore ideas within a Christian environment indicates their belief in a single truth expressed by some pagans and some Christians. This brings us back to the introduction and the question of the history of Byzantine philosophy. It is essential to study texts such as the Elements of Theology which were accepted by a variety of thinkers rather than isolated circles of intellectuals. Nicholas of Methone describes a veritable fashion for Proclus in the twelfth century. ${ }^{21}$ It is also important to study ideas which were deemed acceptable by their contemporaries also at an official level. This does not endorse the dominant culture but allows one to study those who are eccentric within their own context. It is surprising how popular condemned thinkers are in the secondary literature. One may list a few here: John Philoponus (680), ${ }^{22}$ John Italos (1082), ${ }^{23}$ Barlaam of Calabria (1341), ${ }^{24}$ Gregory Acyndinos (1347), ${ }^{25}$ Nicephorus Gregoras $(1351),{ }^{26}$ Prochoros ${ }^{27}$ and Demetrios Cydones $(1368)^{28}$ and even cardinal Bessar-

21 Nicholas of Methone, Refutation of Proclus' Elements of Theology, Proem., p. 20-22: ӧ $\pi \varepsilon p$

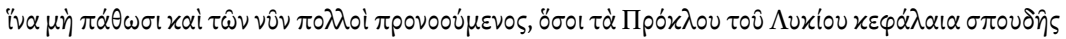

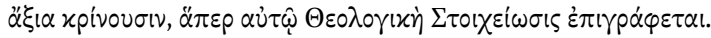

22 Concilium Constantinopoitanum Tertium, in Acta conciliorum 11.480.14-16.

23 Synodikon, p. 184-246.

24 Synodikon, p. 572-633.

25 Synodikon, p. 572-633.

26 Synodikon, p. 640-646.

27 Synodikon, p. 647-665.

28 Synodikon, p. 666-682. 
ion. These figures have become more popular in western scholarship than their counterparts, who are often unpublished and unedited. This fact says much about a certain lack of interest in such ideas that unify official thinkers. The example presented here gives continuity between Proclus, Maximus the Confessor, Michael Psellos and Gregory Palamas, philosophers who defined their own times as well as Byzantine culture in subsequent generations and therefore have an essential role also in the opinions of those who disagree with them.

\section{Bibliography}

\section{Primary Sources}

Acta conciliorum oecumenicorum Series secunda, volumen secundum: Concilium universale Constantinopolitanum tertium, ed. R. Riedinger, Berlin, W. de Gruyter, 199o-1992.

Anonymus, Logica et quadrivium cum scholiis antiquis, ed. J.L. Heiberg, København, Bianco Luno, 1929.

Basilicorum libri LX. Series A, ed. H.J. Scheltema and N. van der Wal, Groningen, Bouma's Boekhuis, 1988.

Codex Iustinianus, ed. P. Krueger, Berlin, apud Weidmannos, 1877.

COG D 1-4 = Conciliorum Oecumenicorum Generaliumque Decreta, ed. A. Melloni, Turnhout, Brepols, 2006-2016.

John Damascenus, Expositio fidei, in Die Schriften des Johannes von Damaskos, ed. P.B. Kotter, vol. 2, Berlin, W. de Gruyter, 1973.

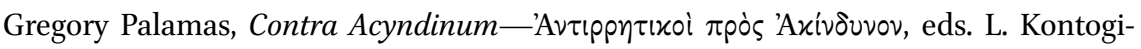

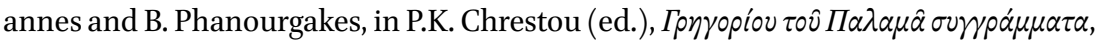
vol. 3, Thessaloniki, Ethniko Idrima Erevnon, 1970.

Gregory Palamas, Triads, in Meyendorff 1973.

G.W.F. Hegel, Phenomenologie des Geistes, Bamberg / Würzburg, J.A. Goebhardt, 1807. Ioannes Malalas, Chronographia, ed. I. Thurn, Berlin / New York, W. de Gruyter, 2002 $\left(2012^{2}\right)$.

L. Feuerbach, Grundsätze einer Philosophie der Zukunft, in Kleine philosophische Schriften (1842-1845), Leipzig, Felix Meiner, 1950.

Maximus the Confessor, On Difficulties in the Church Fathers: The Ambigua, ed. and tr. N. Constas, Cambridge (Mass.), Harvard University Press, 2014.

Michael Psellos, De Omnifaria Doctrina, ed. L.G. Westerink, Utrecht, J.L. Beijers, 1948.

Michael Psellos, Theologica, ed. P. Gautier, vol. 1, Leipzig, Teubner, 1989.

Michael Psellos, Epistola a Giovanni Xifilino, ed. U. Criscuolo, Napoli, Bibliopolis, 1990. Michael Psellos-The Letters of Psellos: Cultural Networks and Historical Realities, ed. M.J. Jeffreys and M.D. Lauxtermann, Oxford, Oxford University Press, 2017.

Nicholas of Methone, Refutation of Proclus' Elements of Theology. A Critical Edition 
with an Introduction on Nicholas' Life and Works, ed. A. Angelou, Athens, Academy of Athens, 1984.

Plotinus, Opera, ed. P. Henry, H.-R.P. Schwyzer, Oxford, Clarendon Press, 1964-1982.

Proclus, The Elements of Theology, ed. and trans. E.R. Dodds, Oxford, Clarendon Press, 1933.

Proclus, In Platonis Parmenidem Commentaria, ed. C. Steel, Oxford, Oxford University Press, 2007-2009.

Pseudo-Dionysius the Areopagite, De divinis nominibus, in Corpus Dionysiacum. I, ed. B.R. Suchla, Berlin, W. de Gruyter, 1990.

Suidae lexicon, ed. A. Adler, Leipzig, Teubner, 1928-1935.

Synodikon: see Gouillard 1967

Codex Theodosianus: Theodosiani libri XVI cum constitutionibus Sirmondianis et leges Novellae ad Theodosianum pertinentes, ed. Th. Mommsen and P.M. Meyer, Berlin, apud Weidmannos, 1905 .

\section{Secondary Sources}

Dölger, F. (1927), Beiträge zur Geschichte der byzantinischen Finanzverwaltung besonders des 10. und 11. Jahrhunderts, Leipzig, Teubner.

Gouillard, J, (1967) “Le Synodikon de l' orthodoxie: Édition et Commentaire”, in Travaux et Mémoires 2, p. 1-316.

Ioannou, P. (1956), Christliche Metaphysik in Byzanz, Ettal, Buch-Kunstverlag.

Kaldellis, A., Sinissioglu, N. (2017), The Cambridge Intellectual History of Byzantium, Cambridge, Cambridge University Press.

Lauritzen, F. (2012a), "Psellos the Hesychast, a Neoplatonic Reading of the Transfiguration on Mt. Tabor", in Byzantinoslavica 70, p. 167-180.

Lauritzen, F. (2012b), "Pagan Energies in Maximus the Confessor: The Influence of Proclus on the Ad Thomam 5", in Greek Roman and Byzantine Studies 52.2, p. 226-239

Lauritzen, F. (2016), "The Renaissance of Proclus in the Eleventh Century", in D. Layne, D. Butorac, Proclus and his Legacy, Berlin, W. de Gruyter, p. 233-240.

Lefort J. (1976), "Rhétorique et politique: trois discours de Jean Mauropous en 1047", in Travaux et Memoires 6, p. 265-303.

Meyendorff, J. (1973), Grégoire Palamas. Défense des saints hésychastes, Louvain, Peeters. Moore, P. (2005), Iter Psellianum, Turnhout, Brepols. 